\title{
The Annales School and the Environmental History of Latin America*
}

\begin{abstract}
Alejandro Tortolero Villaseñor
Profesor de la Universidad Autónoma Metropolitana, Unidad Iztapalapa (México). Correo electónico: tortoleroalejandro@yahoo.com. El autor es doctor en Historia y Civilizaciones de la Escuela de Altos Estudios en Ciencias Sociales de París (Francia). Entre sus publicaciones recientes tenemos: "canales de riego y canales navegables en la cuenca de México: economía, patrimonio y paisaje en el México porfirista" en Historia Caribe Vol. X, No. 26 (2015) y "Francois Chevalier y los grandes latifundios: algunas aportaciones de una obra maestra en el contexto de dos tradiciones analíticas", en Boletín de la AFEHC No. 62, (Julio-Septiembre, 2014). Entre sus temas de interés están la historia económica, tecnológica y ecológica de México, siglos XVIII al XX.
\end{abstract}

Recibido: 6 de mayo de 2015

Aprobado: 10 de junio de 2016

Modificado: 15 de julio de 2016

Artículo de investigación científica

DOI: http://dx.doi.org/10.15648/hc.30.2016.01

* Este artículo forma parte del proyecto: "Para una historia ambiental de México" financiado por la Universidad Autónoma Metropolitana, Unidad Iztapalapa (México).

Esta publicación está bajo una licencia Creative Commons Reconocimiento-NoComercial 4.0 


\title{
The Annales School and the Environmental History of Latin America
}

\begin{abstract}
There are different influences in Environmental Latin-American History. From the historical demography to anthropology, this discipline has been benefit from Cook and Borah's contributions to Carl Sauer's. In this article, my contribution consists in broading the spectrum towards the European influence and particularly to the so-called Annales School. While it is true that this movement had a strong influence in Latin-American History, in contrast, in Environment Historians, such influence has not been comparable to quantity history or the history of prices. My purpose is to analyze the roots of this influence in Latin America, their scope and limits.
\end{abstract}

Key Words: environment, history, France, Latin America

\section{Annales e historia ambiental: encuentros y desencuentros en América Latina}

\section{Resumen}

Existen distintas influencias en la historia ambiental latinoamericana. Desde la demografía histórica hasta la antropología, esta disciplina se ha beneficiado de los aportes de Cook y Borah hasta Carl Sauer. En este artículo mi contribución consistirá en ampliar el espectro hacia la influencia europea y particularmente hacia la llamada Escuela de Annales. Si bien es cierto esta corriente tuvo una fuerte influencia en la historia latinoamericana, en cambio, en los historiadores del medio ambiente su influencia no ha sido equiparable al de la historia cuantitativa o la historia de los precios. Mi objetivo será analizar las raíces de esta influencia en latinoamérica, sus alcances y sus límites.

Palabras clave: ambiente, historia, Francia, América Latina.

\section{Annales e história ambiental: encontros e desencuentros em América Latina}

\section{Resumo}

Existem diferentes influências na história ambiental latinoamericana. Desde a demografía histórica até a antropologia, esta disciplina beneficiou-se de contribua-os de Cook e Borah até Carl Sauer. Neste artigo minha contribuição consistirá em ampliar o espectro para a influência européia e particularmente para a chamada Escola de Annales. Conquanto é verdadeiro esta corrente teve uma forte influência na história latino- 
americana, em mudança, em os historiadores do meio ambiente sua influência não tem sido equiparable ao da história quantitativa ou a história dos preços. Meu objetivo será analisar as raízes desta influência em latinoamérica, seus alcances e seus limites.

Palavras chave: ambiente, história, França, América Latina.

\section{Annales et histoire de l'environnement: accords et désaccords en Amérique Latine}

Il existe d'influences diverses dans l'histoire environnementale de l'Amérique Latine. De la démographie historique à l'anthropologie, cette discipline a été bénéficiée des contributions de Cook et Borah et Carl Sauer. Dans cet article, j'envisage d'élargir le champ vers l'influence européenne, et plus particulièrement, vers l'école des Annales. Il est certain que ce courant a eu une forte influence sur l'histoire latino-américaine, alors que pour les historiens de l'environnement l'influence de celle-ci n'est pas comparable avec l'histoire quantitative ou l'histoire des prix. Mon objectif vise à analyser les racines de cette influence en Amérique Latine, ses portés et ses limites.

Most Clés: environnement, histoire, France, Amérique Latine.

\section{INTRODUCTION}

This paper reviews the influence of the French Annales School in the development of Latin American environmental historiography. I argue that while it is true that this school had a strong influence on Latin American history, for environmental historians this influence has not been comparable to that of quantitative history or the history of prices. Perhaps the origin of this situation can be traced to the school itself. While historians like Worster (1988),Crosby (1995) and Guha (1993) ${ }^{1}$ recognize an affiliation between the Annales School and environmental history to the point where Guha makes Marc Bloch a model for ecological history, for Geneviève Massard this is not as clear and is ultimately a misunderstanding.

1 This work has benefitted from the comments of Maurice Aymard, the working group on Historia Ambiental Latinoamericana, $2^{\text {nd }}$ WEHC-Guimaraes and SEHAM-México. 
My objective here is to analyze this presumed misunderstanding, examine the roots of its influence in Latin America, particularly in Mexico, its extent and its limitations ${ }^{2}$.

\section{ANNALES AND the ENVIronment}

If we were to emphasize the relationship between the Annales School and the environment, we would begin by saying that in its quest for totality, this school assumed that history was predetermined, at least partially, by external forces to man that were not always neutral or foreign to him forces that are partly physical, visible, and practically immovable such as the geography or climate.

Where Durkheim and Berr integrated philosophy and sociology into the history, Vidal de la Blache and his pupil Lucien Gallois, Lucien Febvre's professor in the École Normale Supérieure, made social history an integral part of geography. Through their efforts, agriculture became a gateway to Annales. With this opening, an analysis of the "active and passive" aspects of the relationship between man and earth began. This reciprocal relationship of influences between nature and man resulted in the study of a way of life derived from the relationship between the environment and the social structure ${ }^{3}$.

For example, in his doctoral thesis Philippe II et la Franche-Comte (1911) ${ }^{4}$, Lucien Febvre conducts a detailed examination of the geographical environment and specifically of its agrarian base, which serves to clarify many

2 Donald Worster (ed.), The ends of the earth (Cambridge: University Press, 1988). Alfred Crosby, "The past and present of environmental history", American Historical Review Vol. 100 No. 4 (1995): 1177-1189. Ramachandra Guha, The fissured land: an ecological history of India (USA: University of California, 1993).

3 For a relation between Braudel and the reciprocal influences on Brazilian environmental history, see, J. R. McNeil, J.A Padua and M. Rangarajan, Environmental history, as if nature existed (Oxford: Oxford University Press, 2010), 4, 5. On the matter of a manuscript on the history of Brazil that Braudel did not publish, Maurice Aymard's response is that Braudel never redacted it. See Carlos Aguirre Rojas, "Braudel en las Américas. Ensayo de comparación de dos intercambios transculturales", Signos Históricos Vol. 3 No. 2 (2000): 58.

4 Peter Burke (ed.), Economy and society in early modern Europe: essays from Annales (New York: Harper and Row, 1972). 
aspects concerning the structure of social relationships and the psychological attitudes of the inhabitants of the region. Later, in La terre et l'evolution bumaine $(1927)^{5}$ he calls upon geohistory where the environment plays a pivotal role not only in the movement of goods but also in the evolution of ideas.

Marc Bloch, for his part, strongly embraces geohistory, and in his classic work Les caractéres originaux de l'histoire rurale française (1931) the agrarian landscapes of the Middle Ages, crop rotation, tillage methods, seeds, land claims, cultivation camps, tools, and farmhouses. This work illustrates the division in Europe between the cultivation of crops using a two-field system or a three-year rotation as well as plowing techniques and the enormous importance of the abandonment of fallowing after the adoption of forage crops in the eighteenth century.

In his later work Apologie pour l'histoire ou Metien d'historien (1949) ${ }^{7}$, posthumously published, Bloch tells us of a definitive way of understanding the landscape. He states:

"But let us be aware once more of assuming a falsely geometric parallelism between the natural sciences and a science of men. From the view I have from my window, every scientist takes his own without concerning himself much with the bigger picture. The physicist explains the blue of the sky; the chemist, the water stream; the botanist, the grass. They leave the restoration of the landscape in the hands of others. This appears to me art should the painter or poet take on the responsibility of restoring the land. And the landscape, as a unit, solely exists in my consciousness; and the object of the scientific method, as these forms of knowing are practiced, and thanks to its successes, justified, is to abandon deliberately whoever contemplates in order to know the objects contemplated. To these forms of knowledge, the links

5 Lucien Febvre, Philippe II et la Franche-Comté (Paris: Champion, 1911). 
that our minds weave between things seem arbitrary, are purposefully broken to establish a diversity that in its evaluation is more authentic"s.

Everything is there. On one side there is an objective reality of the landscape that the historian should intend to capture in its diversity and in the complexity of its interactions; on the other side, the landscape is a glance at the external that mobilizes perceptual processes, values, images, subliminal messages and memories.

In sum, human geography led proponents of the Annales School to begin their work, especially with agrarian themes, the study of the physical environment and the milieu mountains, rivers, floors, climates. Human beings are informed through reactions with their physical environment and from these reactions emerge the characteristics that differentiate agrarian societies such as systems of cultivation, tools, animals, property rights, and exchange systems.

There is no one better than Fernand Braudel and La Méditerranée... (1949)9 to explain to us the role of the environment. His book depicts the life of the mountaineers, civilization on the slopes, the changes in the valleys, and the significance of transhumance throughout the centuries in an excellent study of the nomadic life from Castile to Anatolia.

\section{A. Fernand Braudel and the Environment}

In the case of Fernand Braudel, while there are no precise references to ecology, to the extent that his study is an accomplished endeavor to create a dialogue with other social disciplines and present a global view of history, it employs concepts that environmentalists later make theirs ${ }^{10}$.

In fact, if we were to observe two of Braudel's greatest sources of influ-

3068 Marc Bloch, Apologie pour l'histoire (Paris: A. Colin, 1949).

9 Marc Bloch, Apología para la historia o el oficio de historiador (México: FCE, 2003), 147.

10 Fernand Braudel, La Méditerranée et le Monde Méditerranéen à l'époque de Philippe II (France: Armand Colin, 1949). 
ence, Durkheim and Vidal de la Blache, we would begin to notice the presence of the environment as well as some ecological concepts. Durkheim, for example, assumed that "the individual could only be understood within the context of a society and this society manifested itself in concrete forms which could be observed from the outside very much like phenomena of nature" 11 . At the same time, this author intends to identify independent variables of the social psychology of individuals which can contribute to explain the social structure. This social morphology, as well as Vidal de la Blache's ideas on the influence geographical factors have on human behavior, will be important concepts throughout Braudel's work ${ }^{12}$. These authors help Braudel familiarize himself with the impact of the environment and social organization.

This influence is noted in at least four of his contributions: the first states that a social system reproduces itself in a given territory and with the resources that exist within that space; the second is the concept of adaptation; the third is the concept of succession as intrinsic to social change, and the last are the concepts of hierarchy and domination ${ }^{13}$.

Human ecology begins by noting that all living beings require a source of sustainment found in the environment; therefore, social systems must have a territorial base. Braudel depicts this masterfully by enumerating the mountains, the hills, the valleys, the seas, the coasts and islands of the Mediterranean. Essentially, this is about relationships based upon exchange and complementarities existing on three levels: the hills where human settlements are concentrated, the cities; the coastal lowlands, which are sometimes cultivated, other times abandoned and regained by the tides; and, finally, the mountains. He then describes the harvests and the animals used for them; he indicates the locales of the population and their

11 The only reference to the word 'ecology' that we know of is contained in an article about the longterm where he proposes three scientific inscriptions of social reality, in time-history, in space-geography, [and] better yet ecology and mathematical modelling Fernand Braudel, "La longue durée", Annales ESC Vol. 13 No. 4 (1958): 37.

12 George G. Iggers, New directions in European Historiography (Middletown, CT: Wesleyan University Press, 1975), 49-50.

13 Fernand Braudel, El mediterráneo y el mundo mediterráneo en la época de Felipe II, Tomo I (México: FCE, 1992), 70, 160, 246. 
settlement patterns and migration routes. In sum, the geography and history join together to give us answers; they are not an end in themselves but rather complement each other ${ }^{14}$. The environment, then, is not only a starting point but also a continuing presence throughout Braudel's work. The concept of adaptation is employed by human ecology as a continuous process of social control over the environment; for it, the division of labor and the spatial organization of activities are inherent. In this respect, one does not have to fall into the presumed geographic determinism that appears to emanate from Braudel in this phrase: "Behind all human history lies this actor so quick to transform itself, but always so clever, so powerful, and sometimes so decisive in its interventions. What should we call it? Space is an understatement, land is ambiguous, we shall say the geographical environment" ${ }^{\prime \prime}$. The weight of geography seems to lead to a determinism that obliges Braudel to delete this phrase in the second edition of his work, while it never appears in the Spanish edition. On the contrary, geography and history always go hand in hand, and the process of adaptation to the environment emerges as interaction, much as in Vidal's thought, but not in a deterministic manner ${ }^{16}$.

Ecologists have analyzed the universality of social change utilizing the concept of succession. The expansion of a system can occur when surpluses are created over the course of an adaptation to environmental changes. Ecological theory postulates that systematic equilibrium is reached when a system is capable of surviving and preserving itself through time ${ }^{17}$. These

14 James R. Hudson, "Braudel's ecological perspective”, Sociological Forum Vol. 2 No. 1 (1987): 146165.

15 Fernand Braudel, El mediterráneo, 123.

16 Fernand Braudel, La Méditerranée, 3.

17 For Vidal: "Nature provides man with materials which have their inherent requirements, their special aptitudes -also their limitations- and which lend themselves to certain uses rather than to others. To this extents nature does make suggestions, But nature is never more than an advisor". Paul Vidal, Principes of human geography (New York: Henry Holt and Co, 1926): 321. Vidal opposes Haeckel's ecological determinism when he affirms that while they take advantage of their mediums, the development of great civilizations is independent of the environment in which they insert themselves into. However, he never considers this geographical possibility like Febvre does. Georges Bertrand, "Pour une histoire écologique de la France rurale", Dans Histoire de la France Rurale, Tomo 1, eds. Georges Duby et Armand Wallon (Paris: Seuil, 1975) 89. Even in the volume dedicated to the Current Time of his Grammar of Civilizations apropos the great religions like Islam in the Middle East, he points out that they are relatively recent and that they were inserted in the space of civilization prior to them. 
ideas are largely developed throughout Braudel's work, but we will cite only the case of the fishers, which demonstrates the idea of succession, surplus, and equilibrium: "The scarcity of fish explains the scarcity of fishermen, and consequently that of the sailors wich always acted as un unseen brake on the grand projects of Mediterranean powers. Between political dreams and reality there always lay this obstacle: the shortage of men capable of building, equipping, and handling fleets" 18 . Until new boat crews are trained or directed to sail from other existing locations, only then will the system expand. This process also explains the case of the mules necessary for the transport of goods in Spain. The mules were suited for the existing routes and for the goods that were exchanged; the problem was that they consumed grain and the more they consumed the less was available to feed horses. Because of this, the triumph of the mules in the XVI century limited the expansion of the horse ${ }^{19}$. Then there is the example of the expansion of the cities at the expense of the domination of navigation: Braudel asserts that Carthage, Marseille and Genova could have solved the problem of navigation toward the west, overcoming the winds of the east, the dangerous levant and mistral, by constructing heavier marine vessels ${ }^{20}$. These examples demonstrate how the social systems could only be manipulated by maintaining a close relationship with environmental conditions.

Hierarchy and dominance: In Braudel's works, the economic system was dominated by agriculture, but its distribution and exchange were directed through cities. Here we find that the urban centers played a central role as points of transportation, communication, organization, and administration. With that said, not every center was the same. Within each existed a hierarchy-some cities dominated a region or urban system and others

18 In their monographs on the countryside, the French geographers of the 1930s spoke of the argo-silvo-pastoral equilibrium when describing the relationship between crop fields, forests, and pastures. Braudel, for his part, highlights the fact that the intensification of the cultivation of rice -made possible through irrigation- generated a sharp decline of cattle and a growth and compensation of human labor.

19 Fernand Braudel, La Méditerranée, 181.

20 In his words, "It is this traffic (the convoy of beasts en route) that permits Castile to serve as a link between the peripheral regions of the peninsula... It is this traffic that has made Spain". Fernand Braudel, El Mediterraneo, t.1, 68. 
that inserted themselves inside of these systems. For Braudel, a great city meant being surrounded by a ring of secondary villages, or a ban sheltering factories, ports, etc. Cities are the creative forces of civilization, the sites of innovation, and the sources of social change. Pierre Goubert concurs when he states that the cities of the Old Regime "have taken each time more and more the direction of the kingdom. They concentrate riches, talents, all that shines, all that matters, all that is associated with power, potency and culture"21. The urban minority dominated in the Old Regime. In contrast to the analysis later undertaken by Foucault, Braudel and Goubert see the city as a space of social tolerance and freedom ${ }^{22}$.

Beyond discussions of hierarchy and the dominion of cities $^{23}$, what we find in Braudel is the proposition of a holistic vision in analyzing social systems. The parts of the system are irreducibly interconnected with each other. While it is possible to analyze the subsystems within a larger system, one cannot isolate them from the system in which they are inserted. For Braudel society is the "group of groups", which encompasses everything, but does not always mean interconnection. Essentially, Braudel, in criticizing traditional history for its narrowness and trivial details, proposes a global focus, a total history written on three different levels and in three different times: short term, long duration, and one of events. The coexistence of these three levels, conflicts and contradictions, come together to form a different history, a total history whose principles environmentalists have incorporated in their efforts to develop social systems.

In effect, ecology has posited similar approaches to studying the social system "as the product of an irreversible process, and as a constituting, therefore, a unit that cannot be resolved into its parts except for analytic purposes" 24 . The fundamental problem is how populations survive in time

21 Fernand Braudel, El Mediterraneo, t.1, 160.

22 Pierre Goubert, "Les villes d'europe à l'époque moderne", Revista de Historia Vol. 4 (1981): 121 132. http:/ /ler.letras.up.pt/uploads/ficheiros/6534.pdf (30 de diciembre de 2015).

23 Foucaultism notes that the city is the place and means for a reinforcement of power, it is the place where methods of discipline and the control of the lower classes are implanted, and where mechanisms of social control and restraint appear (prisons, hospitals, etc.). The city is converted from a space of liberty to an instrument of power.

24 Marxism, for example, allowed for the study of how the capitalist order was serviced by a certain 
and how they change in their interactions with the physical and social environment. Like ecologists, Braudel studies social systems from a macro level. For Braudel different natural resources can oscillate, in space, but also in time, between abundance and scarcity. This is valid for soil, water, and the forest, and Braudel even outlines that air, along with atmospheric contamination, will turn into a scarce resource, which will demand specific investments in order to be recycled and refreshed. In his projections the spectrum of English deforestation appears, whom maximized the use of coal, and peat consumption in Holland, the point of departure for the industrial revolution. He also includes the population among the resources: the hunter-gatherer civilizations would become the victims of sedentary agriculturalists.

Following the seminal scholarship of Braudel, there is a surge of varying works, dealing with environmental issues (Berthet, 1951; Lombard, 1969; Devèze 1960) $)^{25}$, which we will review in the following section.

\section{B. Agrarian History and the Environment}

For the forested zone of the Upper Jura, Bernard Berthet (1951) studies the uses of the forest between the XV and XVI centuries. During the VI century, this region of about two hundred thousand hectares of forest was utilized by only 300 to 400 religious of the Abbey of Saint-Cloud; this situation, however, soon changed after the arrival of new players in the XVI century.

In effect, the Abbey of Saint-Cloud, given the abundance of the forests, permitted the families of the monks to practice the cutting of wood and the grazing of their animals for low fees or even for free. For the religious, only the deforested land was productive because it was on these lands that

policy, essentially that of the state. Here the space of the cities projected a series of social relations and, according to Marx, every division of labor associated with the exchange of goods is fundamentally based in the separation of the city and the countryside. Western history was a good example to study how the bourgeoisie of the cities took control of the country. 
the wheat, which was tithed, was produced, and this tax was a fundamental resource for the abbey. Contrarily, there was no tithe placed on wood. Despite officially belonging to the abbey, the forest is a public good, a treasure where everyone, monks and inhabitants alike, could use the space while the population remained sparse.

As families increased, so did the consumption of the forest, necessitating the redefinition of living spaces of the forest. If in the XVI century, all of the inhabitants have rights over the forests of the abbey, little by little, a process of deforestation and land reclamations begins, which concedes property to the tillers, diminishing the forested area ${ }^{26}$.

The uses of the forest varied, first, as pastures for the herds of goats and cattle led there in the first four months of summer to graze. From these herds, inhabitants fed themselves with milk, butter, and cheese. So important was this, that in their wills, men left their women a pension of butter, cheese, and "serrat". Inhabitants also feed themselves with the meat of these animals. Secondly, the forest supports the collection of dry twigs, branches for domestic and livestock use, and of wild fruits (cherries, raspberries, strawberries, and maybe even wild honey). Thirdly, hunting is practiced in the forests. Bears were abundant in the XVI century as well as other hunting game including hares and deer. In theory, the Abbey attempted to retain the rights to hunt and fish but did so only if the offense affected it, for example with the consumption of a lot of fish.

Wild animals killed by peasants were shared in part with the religious who compensated them. When gifts to judges and lawyers were necessary, the Abbey bought pieces of deer and wild boar from the peasants. Fourthly, the cutting of forest trees provides timber to construct and repair houses, cook, and warm the homes. Everything is made of wood: the cooking utensils, the locks of the houses, the irrigation canals which transported

26 Bernard Berthet, "De la forêt inutile à la forêt précieuse dans le Haut-Jura, au XVe et au XVIe siècle", Annales ESC Vol. 6 No. 2 (1951): 145-153. Maurice Lombard, "La chasse et les produits de la chasse dans le monde musulman (VIIIe-XIe siècle)", Annales, ESC Vol. 24 No. 3 (1969): 572-593. Michel Devèze, "Superficie et propriété des forêts du Nord et de l'Est de la France vers la fin du règne de François 1er. (1540-1547)”, Annales ESC Vol. 15 No. 3 (1960): 485-492. 
water to the mills, the arms of the wells, and the granaries. The risks of fire from chimneys and kitchens inside of houses obliged inhabitants to store papers and legal documents in separate barns.

With the arrival of laymen, changes resulted, which the author summarizes in the account of the Mount-Jura rebellion in the XVIII century against the demands of the abbey, demonstrating clearly an evolution from a good that was abundant to one in which each time more and more actors multiplied the uses and demands made of the forest.

Maurice Lombard, for his part, shows us a series of geographical charts of the timber trade in the Muslim world between the VII and XI centuries. Although his work recognizes timber as a necessity for the Muslim economy, the author, in the purest tradition of Annales, gives us a work of economic history and historical geography that for him consists in the study between man and nature ${ }^{27}$. Braudel's influence can be found in the region of study as well as in the disciplines Lombard integrates in his analysis and in his form of addressing a three-fold approach: structural, long-duration, and conjunctural.

In effect, his charts offer the reader a structural element, the lack of wood in the Mediterranean world and the fragility of the forest in the region; an element of long duration, the continuous degradation in the forested area exploited since antiquity; and finally, an element of conjuncture. The economic juncture that increases the demand of timber (larger fleets, new cities, new places of worship, new zones of irrigation, new mines); the technical juncture, new shipping techniques that increase the consumption of timber, new manufacturing techniques such as in the sugar industry which needs more wood for fuel; the military juncture, which modifies the domination of the wooded areas of Crete, Syria, and Sicily ${ }^{28}$.

This work demonstrates how in the face of the scarcity of forests and wooded resources, Mediterranean Muslims, trapped between the desert

27 Bernard Berthet, De la forêt inutile..., 150.

28 Maurice Lombard, "Un problème cartographie. Le bois dans la mediterranée musulmane (VIIe-XIe siècles)”, Annales ESC Vol. 14 No. 2 (1959): 234. 
and the sea, had to search their coastal neighbors like Anatolia, Dalmatia, Italy and Spain or on islands like Cyprus, Crete, Sicily, Sardinia, Corsica and the Balearic Islands, for the resources required by long distance maritime trade. This is what leads to the destruction of broad, forested areas, as indicated by, for example, Strabo, who at the beginning of the Christian era writes of Cyprus:

\begin{abstract}
"Toutes les parties basses de l'île, anciennement, étaient tellement boisées que les arbres envahissaient tout en ne laissaient pas, à proprement parler, de place a la culture. L'exploitation des mines, à vraie dire, enraya un peu le mal en nécessitant de fréquents abattis d'arbres pour cuire et fondre le cuivre et l'argent; puis à ce premier remède vint s'ajouter le développement des constructions navales" 29 .
\end{abstract}

Here appear some of the causes that Lombard later signals as factors of deforestation: the opening and rotation of the land, minerals and metals, boats and fleets, to which one must add the nomadic shepherd who incites fires in the forest to transform them into pasture for his animals. Thus between the VII and XI centuries we see how timber is a resource that mobilizes large fleets and financial resources.

Michel Devèze, for his part, shows us the decrease of the wooded areas in the XVI century in the northern and eastern forests of France ${ }^{30}$. While it has been estimated that France's forested area remains practically unchanged between 1380 and 1980, this does not mean that during the XVI century the area did not experience a significant reduction ${ }^{31}$. For the author, an important figure in the research of forests of France, the reasons for this reduction vary: rising timber prices, deforestation and land rotation, the practice of écobuage or slash-and-burn, population growth, an increase in the metallurgy and glass industries, and urban demand ${ }^{32}$. The

29 Maurice Lombard, Un problème cartographie..., 252.

31430 Maurice Lombard, Un problème cartographie..., 239.

31 Michel Devèze, Superficie et propriété..., 485-492.

32 Woronoff estimates that in 1380 there existed 14 million hectares of forested area; this number decreases by half in 1820 and does not reach its original numbers until 1980. Denise Woronoff, 
fortification of Tours in 1592 alone required more than 250,000 pieces of timber, each two feet in diameter, and close to 20,000 carriages. Devèze devotes himself to studying the history of institutions under the royal administration of waters and forests during this century, and in Annales he shows us one of his geographical charts.

The path which created environmental history seemed facilitated by these seminal works, appeared to detach itself, firstly from the issue of a magazine dedicated to the topic of environmental issues (Annales, 1974), and a year later, by the great Georges Bertrand to make an ecological history.

\section{Emannuel Le Roy Ladurie and Georges Bertrand}

In 1974, in the presentation of the issue of the journal, E. Le Roy Ladurie affirmed:

"Environmental history unites the oldest themes with the newest in contemporary historiography: the evolution of epidemics and climate, those two factors being integral parts of the human ecosystem; the series of natural calamities aggravated by a lack of foresight, or even by an absurd "willingness" on the part of the simpletons of colonization; the destruction of Nature, caused by soaring population and/or by the predators of industrial overconsumption; nuisances of urban and manufacturing origin, which lead to air or water pollution; human congestion or noise levels in urban areas, in a period of galloping urbanization". In this issue, we have explored only some specific themes. However, we have not had the intention of ceding to the dictates of fashion. For a long time, the Annales has been interested in the problems of an ecological history that concerns both the paroxysms of contagious diseases and weather fluctuations. To dedicate ourselves to studying the environment with the goal of fixing the real problems and rejecting the advantages of a vul-

"Histoire des forêts françaises, XVIe-XXe siècles. Résultats de recherche et perspectives", Cahiers du CRH No. 6 (1990): 6. 
garized discourse is primarily and above all else to be faithful to ourselves" $" 33$.

The problems studied in the journal are those of the environment, population and technology in primitive societies (Boserup) and of the environment and development models (Sachs). With this issue it appeared that French environmental history had finally acquired a patent that, from Braudel to Le Roy Ladurie, passing through Deveze, Berthet and Lombard, enabled it to export worldwide an environmental dimension in historical analysis. The Annales appeared in the origin of the distinct schools of environmental history, and the proof was in the works of the two figures Crosby or Guha for whom there is an affiliation between the Annales School and environmental history to the point that Guha makes Marc Bloch a model for ecological history ${ }^{34}$.

Few were the discordant voices. The most authorized voice was that of Georges Bertrand, who just a year after the Annales journal devoted the issue to history and ecology, in the great work of synthesis on the rural history of France, directed by Georges Duby, noted that for the creation of an environmental history of rural France, more in line with the approximations of Max Sorre, Braudel or Le Roy, there hardly existed any ecological study with historical purposes. In his proposal, the historical interpretation of natural factors, in their relationship with society and the agrarian structure, is one of the most badly studied issues; it is, indeed, rarely broached and poorly raised amongst the themes of agrarian history ${ }^{35}$. This is largely due to the historian's belief that this field is for the

33 Again, Woronoff calculates that an industry in this proto-industrial stage consumed 100 hectares of forests annually, for which one should count two thousand hectares considering the period of its reproduction. The écobuage consists of creating fires to clear the lands utilizing the ecobua or hoe as an instrument. In English this practice is called "paring and burning".

34 Emmanuelle Le Roy Ladurie, "Histoire et environnement", Annales ESC Vol. 29 No. 3 (1974): 673 692.

35 Ramachandra Guha, How much should a person consume? Environmentalism in India and in the US (USA: University of California press, 2006), 21. Here he affirms that unlike British Marxist history which is unconcerned with geography, the Annales School does the opposite. Febvre and Bloch were environmental historians before the emergence of this discipline. Ramachandra Guha, How much should, 21. Also in his ecological history of India, he affirms that Bloch was a model of ecological analysis. Ramachandra Guha, The fissured land, 7. See also Alfred Crosby, The past and, 1177-1189. 
geographer concerned with topography, climate, ground, water, vegetables and animals, in sum, the natural environment; from this follows the absence of an ecological dimension in historical analysis.

Thus, the traces of deforestation, irrigation, erosion, and reforestation, when addressed by historians, are done so through the observatory of the economy and social and juridical relations but hardly ever from the viewpoint of nature or the environment. Bertrand proposes to study ecosystems and agro-ecosystems in order to understand the dialectical relationships between the evolution of rural societies and their environments. In contrast to the stationary order of the country, Georges Bertrand highlights the unstable equilibrium of ecology, but also the multiplicity of everyday gestures, cultural behavior, legal realities, and technical practices that influence the transformation and transmission of the landscape ${ }^{36}$.

Nevertheless, his proposal was relegated in comparison to the importance of founders like Bloch and Febvre, the global resonance of Braudel's thesis projected by Le Roy Ladurie, and the stated affiliation with the Annales school that Crosby, Guha, and many others made. In this context, the first works of environmental history had as their capital Parisian universities. Because this area had an unusual number of exiled Latin Americans during the 1980s, the influence of the Annales consequently reached Latin America by means of these exiled Latin Americans in France that complemented the efforts French professors teaching in Latin America made to spread their missions.

\section{France: The Latin American Capital for Exiles}

By the late seventies, Paris had become a heterogeneous recipient of Latin Americans, many of whom had escaped dictatorships (Argentina, Brazil, Chile, Guatemala), others beneficiaries of oil revenues (Mexico and Venezuela), and finally persons attracted to the image of Paris as a capital for Latin Americans (Peruvians, Costa Ricans, Dominicans). Like a magnet, the City of Light attracted Latin Americans of distinct origins unlike any

36 Georges Bertrand, Pour une histoire..., 38. 
other city in the continent ${ }^{37}$. The Latin American novel is a testament to Paris' vitality for writers and Rayuela and Terra Nostra, published in 1975, are testaments to this. Carlos Fuentes makes Polo that multiple referent figure of his novel, a Mexican exile living in Paris.

There networks are established which link historians like Ruggiero Romano or François Chevalier. Among them, the first is a close collaborator of Braudel, the second, a disciple of Bloch. In the seminars of these two major historians, networks are created which spread in Latin America the propositions of the founders.

\section{A. Romano, Chevalier, and their networks}

Ruggiero Romano, for example, encouraged by his teacher Federico Chabod, leaves Italy in 1947 to meet Braudel and Lucien Febvre, personal friends of Chabod. Braudel's teachings and his interactions with Febvre, Labrousse and all of the group of the Annales introduce him to a new project of history very different from German culture, and its idealism and historicism that he had learned in Naples. The Section VI project of the Ecole practique des hautes etudes (EPHE), directed by Febvre and Braudel, was not exclusively French: it proposed economic history as a key to opening the doors of the world ${ }^{38}$. Through the study of the production, circulation, and trade of various commercial goods, the project endeavored to reach a more profound history than that of the political, diplomatic, or military history, one quieter but also more determinant for the lives of societies and people, and indifferent to political and linguistic borders. Its geographical openness is closely related to its methodological, theoretical, and conceptual openness ${ }^{39}$. Section VI is constructed, as we

37 Alice Ingold, "Ecrire la nature. De l'histoire sociale à la question environnementale", Annales HSS No. 1 (2011): 18.

38 Zacarias Moutoukias, "Ruggiero Romano dans l'historiographie latino-américaine: idées et parcours d'un batisseur exceptionnel", in Ruggiero Romano. Incontro di studi, ed. Paulo Betti de Lima (San Marino: Giugno, 2012, 2014), 66.

31839 Romano evokes the creation of the VI Section as follows: 1949 was also the year the Centre for Historical Research was created which at that time was the VI Section of EPHE ... which Lucien Febvre was the Director of, Fernand Braudel the Secretary General, and I, who had meanwhile entered the National Center for Scientific Research system, was the messenger, operator, typewriter ... 
know, around a journal, Lucien Febvre and Marc Bloch's Annales, and an innovative history. There, Romano directed 44 doctoral theses and 9 masters theses, 16 of which were of European origin and 33 of which were of Latin American origin.

Romano's teachings, inscribed in the renovation of EPHE, were aimed at the history of the prices (A. Arcondo, E. Tandeter, E. Florescano), trade and commercial ports (J.C.Garavglia, Z.Moutoukias), agrarian structures (M. Burga, N. Carreño, J. Gelman, G. Palma Murga, A. Tortolero), mining economies (M. Carmagnani, Ch. Cordonnier, J. Deustua, S. Alvarez), Indians and the Spanish conquest $(\mathbb{N}$. Wachtel, A. Flores Galindo, G. Rozat, M. Azoulai, A. $)^{40}$, cities and their economic and social function (H. Iparraguire, $H$. de Gortari), and were, in sum, back and forth issues driven by Section VI of the EPHE.

In this renovation of themes and methods, Romano does not neglect the environmental aspect and, as proof, at least two of his works, about the history of the forests and the mountains, appear. In the first work, Romano expounds, in the purist form of Annales, the relationship between economic history and the history of the forest ${ }^{41}$. For this he presents three examples. The first is of Venice. Here, Romano studies the relationship between the construction of boats, the Venetian fleet, and the utilization of wood. The author states that in order to supply the arsenal of the Sérénissime, it was necessary to cut down between ten and twenty thousand beeches of the Alpago forests for the fabrication of oars. He also notes that construction, the glass industry, and the heating of homes demanded

and the only researcher Nathan Wachtel, "Ruggiero Romano, un historiador en la Escuela de Altos Estudios en Ciencias sociales” In Construir la historia. Homenaje a Ruggiero Romano, coord. Alejandro Tortolero (México: UAMI-ColMex-Colmich-I.Mora-UAEM, 2002), 49. Alberto Tenenti, who in 1949 was appointed temporal associate investigator in the CNRS and, in the years that followed, was renewed in the CRH, would have to be added.

40 Maurice Aymard, "Ruggiero Romano y la historia europea". en Construir la historia. Homenaje a Ruggiero Romano, coord. por Alejandro Tortolero (México: UAMI-COLMEX-ColMich-I. Mora-UAEM, 2002), 42.

41 Wachtel affirms that: "Dans le bureau de Romano surgit l'idée d'étudier la Conquête espagnole au Perou mais traitée à l'inverse de la perspective traditionnelle: du point de vue des Indiens. Ce renversement de l'européocentrisme s'inspirait également de l'esprit des Annales", Nathan Wachtel, "Ruggiero Romano, l'Ecole des hautes études en sciences sociales et l'Amérique Latine", in Ruggiero Romano. Incontro di studi, ed. Paulo Betti de Lima (San Marino: Giugno, 2012, 2014), 47. 
large amounts of wood; it is worth noting that in 1532 a magistracy of firewood (le Magistrato alle legne) was created to deal with the commerce of firewood for the homes and furnaces of Murano. Romano also studies the modifications in social relations, noting that wherever arsenal officials arrived, there were ruptures: the end of communal autonomy, if the forests were communal property, or reduction of seigneurial powers in the case of privately held property. Indeed, he leaves open the hypothesis that it was not only wheat, commerce, or strategic reasons that determined Venetian expansion on the mainland, Istria or Dalmatia, but also perhaps the search for timber.

The second example is the mining colony in Huancavelica and Potosí. The first case takes place in a sufficiently important forested region in 1564, and just five years later the region is deforested. The situation borders on disaster until wood is replaced with a grass, the icho (stipa ichu), rich in sulfur and nitrate, sufficient enough to help the mercury mines reach their sublimation point. The wood was also used in the formation of necessary galleries in Huancavelica as well as in Potosí. In this second mining region, at a height of nearly 4000 meters, the forests were very scarce, and this region is described in a text from 1753 as, "very frigid, bland, and barren land, which if not twelve leagues, the closest, does not produce fruit of grains, nor of trees". Here no icho can act as a substitute for wood fuel, and it is therefore not surprising to note that in 1603 , of the 30,000 indigenous workers in the mining operations, 3,700 were designated for the transportation of wood over long distances ${ }^{42}$.

The third example is hunting. In the tradition of works such Lombard's (1969) which studies the differences between hunting in Western forests, where it appears almost as a sport of the noble life, or as a product of the ancient relationships between man and a hostile environment, which provides food and dress, and is contrasted with the Muslim world ${ }^{43}$, Romano

42 Ruggiero Romano, "Histoire des Forêts et histoire économique". in Actes du Colloque sur la forêt (Besançon, 21-22 octubre 1966), Cahiers d'études comtoises, Les Belles Lettres No. 12 (1967): 59-65.

32043 Ruggiero Romano, Histoire des Forêts, 64. Chantal Cramaussel, an active participant in Romano’s seminar, developed these ideas outlined by Romano three decades later. Véase: Chantal Cramaussel, "Sociedad colonial y depredación ecológica. La provincia de Santa Bárbara". En Sociedad y medioambiente en América, comp. Bernardo García Martínez y Alba González Jácome (México: 
studies a vast literature regarding hunting and the relationships between lords and their subjects.

Romano's other work is about the mountains and their history. There the author describes with more precision the importance of the different ecological levels that sustain an Incan economy based on reciprocity and redistribution; reciprocity in the exchange of goods and services and redistribution of these same goods and services at the local level as well as the redistribution of the center to dependent zones ${ }^{44}$. There the mountain is an important factor, above all when the Spanish arrive and impose a new economic organization for which the concept of vertical control introduced by Murra assumes a lot of force, as we shall see.

To begin with, the mines of Potosi and Huancavelica are between 3000 and 4500 meters in altitude. How were products expected to be delivered on pre-Hispanic paths intended for light traffic? If in the Puna highlands we find potatoes, llama meat, and later sheep, it is necessary to search for everything else further away. Corn, corn liquor but also timber and coal all came from outside ${ }^{45}$. For these goods, it was necessary to bring mules from Jujuy to the northern Pampas who could carry logs and firewood that the llamas, limited to a maximum load of $25 / 30 \mathrm{~kg}$, could not. These labors were fulfilled by the thousands of Indians previously mentioned.

Coca, of which Juan de Matienzo declared that "if it was lacking, everything was lacking", had to be transported from heights between 800 and 1000 meters to the mines of Potosí where in 1603 a minimum of 20,000 baskets of coca were consumed. Each llama could transport two baskets; therefore, approximately 10,000 trips from the hot valleys of La Paz to Potosi, over a distance of approximately $575 \mathrm{~km}$, were required.

The control of ecological levels is therefore an important factor that since the pioneering works of Carl Troll $(1931)^{46}$, to John Murra $(1978)^{47}$ and

COLMEX/Sociedad Panamericana de Geografía, 1999), 93-107.

44 Maurice Lombard, La chasse et, 1969.

45 Ruggiero Romano, "Quand la montagne a aussi une histoire”, Mélanges offerts à Jean-François, ed. Martin Körner y François Walter (Berne: P. Haupt, 1996), 7.

46 Romano mentions a description of 1603 which detail the products that arrived to Potosí (wheat flour, flour, corn, wine, potatoes, ham, coca leaves, peppers, cheese, honey, fish).

47 Carl Troll, "Die geographischen Grindlagen der Andinen Culturen und des Inkaeriches", Ibero 
even Romano (1996) ${ }^{48}$ has been identified as an integral part of a complex theory of the operation of the economy and the pre-Inca Andean state.

François Chevalier's work, for its part, demonstrates the virtues and limits of applying the teachings of Marc Bloch in Mexico. His La formation des grands domains au Mexique, submitted as a doctoral thesis in France in 1949 and published in Spanish in 1956, was a turning point in the historiography of Mexico. The main reasons for its influence in Mexico were, in my opinion, its ability to synthesize historical issues and open new perspectives, with a method grounding itself on ethnohistory, comparative history, historical geography, and the incorporation of new primary sources. It certainly became a necessary reference. While the representation that emerges from Chevalier's work over the Mexican countryside is completely new from a methodological point of view, it also entered into a current of analysis that saw the Mexican countryside immersed in backwardness because of the inefficiency of the great estates ${ }^{49}$.

Chevalier's references on this matter are varied and surprising because although the author mentions on numerous occasions his intellectual indebtedness to his teacher Marc Bloch, whom inspired him to study the large estates as well as the utilization of a regressive and comparative method, he also disassociates Bloch for his analysis of the large estates as bearers of change. This thesis is central in his work although he slightly modifies it beginning in 1975, and in the republication of his work, he does it with more vigor $^{50}$.

This however is not the place to analyze the issue of the inefficiency of the large estates but rather his debt to the master ${ }^{51}$. The ways in which

Amerikanisches Arkiv 5 (1931).

48 John Murra, La organización económica del estado inca (México: Siglo XXI, 1978).

49 Ruggiero Romano, Quand la montagne..., 285-288.

50 We understand by innovation the adoption and application for a group or social sector, of an idea, an instrument, or method in a determined space or time. For the analysis of the dominant vision of the countryside see Alejandro Tortolero (Coord.), Tierra, agua y bosques: historia y medioambiente en el México central (México: CEMCA-I. Mora- U de Guadalajara, 1996), 7-36.

51 In 1975, Chevalier slightly modifies his principal thesis when he admits that beyond the manorial 
Marc Bloch inspires Chevalier's work are constant and extend from comparative to regressive history, which help to comprehend the present through the past and vice versa. Bloch taught Chevalier how to observe the terrain from the plans, land registries, and aerial photographs; to look at the shapes and size of fields and plots; to understand the layout of farm houses, the various types of rural landscapes and "naturally through the men who did everything" 52 . For Chevalier, Bloch was "the master of the history of the land and those that worked it" and for that, he never fails to show his gratitude to this historian. Furthermore, Bloch, who himself invited the comparison when speaking of the manor, introduced the Mexican home like the manorial European property that had a proprietary with their own subjected population ${ }^{53}$.

In La formation des grands domaines, we find the best transference of ideas from the master Bloch to Mexican rural historiography. In addition to the methods already mentioned, Chevalier, in his lengthy chapter, assumes the responsibility of analyzing the "cattle lords», the rich and powerful men of the north, Bloch's ideas over the advancement of agrarian individualism, and the struggle to impose enclosures and abolish the grazing rights in New Spain.

Chevalier's work is now a classic; before him no one had done an analy-

model existed in particular the modern sugar mills of Morelos which possessed the Porfirista technocrats, and in the republication of his work, he accepts that "«il est certain aussi que le modele seigneurial du XVIIe siècle doit être discuté, nuancé et completé, et qu'il y a des exceptions ou de cas régionaux depuis cette époque»". François Chevalier, La formation des grandes domaines au Mexique. Terre et société, XVIe, XVIIe, XVIIIe siècles (Paris: Karthala, 2006), 36. Here, the author marks a distance with the analysis of Molina Enriquez.

52 François Chevalier, Boletín de fuentes para la historia económica de México No. 2 (1990): 37-42. Notes his closeness with Bloch: "“... there were various teachers, historians that influenced my research, but perhaps the one who had the biggest influence was my professor March Bloch, a renowned medievalist... Bloch pondered the importance of the economy but never separated it from its socio-political aspects, of the study of power...»". Most recently, he affirms this closeness when he says that he was influenced " "... above all by an illustrated medievalist historian from the Sorbonne, Marc Bloch, who naturally based his investigations in old archives but also utilized fieldwork and the observation of the territory since it did not establish a rupture between the past and the present. He also practiced 'regressive history', a term coined by him. I had a great admiration for his books, The Original Characters of the French Rural History (Oslo, 1931), The Feudal Society and many others situated in the 'long duration' over which Fernand Braudel insisted". François Chevalier, "Orígenes y elaboración de los grandes latifundios en México. Tierra y sociedad en los siglos XVI y XVII”, Signos Históricos Vol. 17 No. 17 (2007): 34.

53 Chevalier, Boletín de fuentes, 11. 
sis of prices, no one had come up with a vision of two centuries for the whole country, no one had applied a regressive or comparative method, no one had introduced geographic history like him, no one had analyzed primary sources from European, Mexican, and private estate archives. In short, no one had achieved as solid approximation as Chevalier. The author does not generalize his studies based on four estates like Molina Enríquez but rather does so based on the knowledge of the techniques and methods of French historiography applied to the study of large Mexican properties that he recognized directly through his motorcycle rides; as well as because of his preoccupation with ethnohistory, and his eagerness to find the sources ${ }^{54}$.

In introducing the geography, Chevalier also becomes a pioneer in contemporary analyses that, as in matters of water, he develops before it becomes popular. The same author noted as one of his contributions the inspiration of one of the principal works about rural conflict in Mexico. I am referring to John Womack's Zapata and the Mexican Revolution. This work has also become a classic in Mexican agrarian history, but in my analysis there are new elements that we should integrate into the explanation of this conflict and that Chevalier had already noted when he mentions the struggle for water in colonial Mexico as an important element in the study of such conflict.

In effect, Chevalier notes that communities lost their irrigation water many times, this was particularly important in a country where 6 to 7 months out of the year there is no rain, and that in the immense semi-arid northern plains, the fight for water took on a sharper character ${ }^{55}$. Chevalier

54 Bloch affirms: «LLes redevances et les corvées qui les grevaient n'avaient été primitivement que la marque de la dépendance où les habitants s'étaient trowvés envers un chef de village, de tribu ou de clan ou un patron de clientèle, peu à peu mués en seigneurs véritables. En fin-de même qu'au Mexique on voyait récemment voisiner avec les 'baciendas' des groupes de paysans propriétaires- il subsistait encore une quantité notable d'authentiques alleux ruraux, exempts de toute suprématie seigneuriale»». Marc Bloch, La société féodale..., 371.

55 The comments of some historians underpin this idea. Bernard Lavallé, for example, following E. Van Young, mentions the Chevalier's contributions to agrarian history noting: "«Grâce à l'utilisation magistrale que le chartiste a su faire d'une masse considérable d'archives jusque-là inexploitées, François Chevalier a fait passer l'hacienda du niveau de l'abstraction quelque peu mythique et très souvent faussée par le débat idéologique, à celui de la réalité historique à la fois précise, concrète et surtout vivante» Bernard Lavallé, "Introduction", in Structures et cultures des sociétés ibéro-américaines (Bordeaux: Editions du CNRS, 1990), 8. Bakewell, for his part, mentions that Chevalier's work, has served as a point of departure, or of reaction, for much of the voluminous new work on 
also notes the importance of water to the sugar mills; however, the thesis remains the same that the earth was the central explicative element from which the Zapatista uprising originates. With the emergence of environmental history, we have had to refine this image ${ }^{56}$.

If this generation of founders does not sidestep the environment in their proposals, whether because of its proximity to geographical history, the propositions of Febvre, Bloch, and Braudel, or the explanatory power of these factors, the truth is that few of their Latin American alumni would be inclined to conduct their own studies on environmental history. Faced with the adoption of important themes driven by the Annales (prices, commerce, structures, etc.) environmental history was barely broached by a handful of researchers, as we shall next see.

\section{B. From reciprocity and redistribution to complexity and integra- tion: the followers}

Enrique Florescano is, without a doubt, one of the principal diffusers of the contributions of French historiography in Latin America, but especially in Mexico ${ }^{57}$. His study of the prices and agricultural crises are part of the best traditions of E. Labrousse ${ }^{58}$. With this seminal work, he begins to study the consequences droughts have on the population and structure of production. During the XVIII century, the violent droughts and associated agricultural crises decimated Mexico City's population causing, over the century, the death of 123,678 persons, a little more than the total population in 1790. The crisis of 1736-1739 generated a loss of $50 \%$ of

colonial land, and rural society that has appeared in México, the United States, Canada and Western Europe. Peter Bakewell, "An interview with François Chevalier", Hispanic American Historical Review Vol. 64 No. 3 (1984): 421. Finally, Van Young gives the most detailed analysis of Chevalier's contributions to the development of Mexican agrarian history and affirms that Chevalier told us everything we needed to know about the rich and powerful men of the Mexican countryside. Eric Van Young, "An interview with François Chevalier", Hispanic American Historical Review Vol. 64 No. 3 (1984): 8.

56 François Chevalier, La formación de los latifundios en México (México: FCE, 1976), 172-173.

57 François Chevalier, La formación de, 215. For an actual analysis see Alejandro Tortolero, "Water and revolution in Morelos: 1850-1915", in A Land between waters. Environmental Histories of Modern Mexico, ed. Christopher R. Boyer (USA: The University of Arizona Press, 2013), 124-149.

58 A model of a study that engages with the cultural transferences, like the ones Florescano carries out in Mexico, is that of Michel Espagne y M. Werner, "La construction d'une reference culturelle allemande en France. Genèse et histoire (1750-1940)", Annales ESC Vol. 42 No. 4 (1987): 969-992. 
the population of the capital of New Spain, and the crisis of 1808-1810 accompanied the revolutionary movement of 1810 .

Florescano, now inspired by Emmanuel Le Roy Ladurie, affirms that when the French historian conducts a history of the climate beginning with the year 1000, he also studies men; therefore, this study becomes an "ecological history" and this is what Florescano makes when he relate the drought with the economy, politics, and society from remote to present times ${ }^{59}$. Although the historical record is poor, the author notes that droughts have been present in Mexico as early as 1500 BCE. Then, during colonial times, Mexico suffered a growing climate warming, and during the independence period, the land experienced intense droughts that lasted until the end of the XIX century. During the XX century, the drought increased between the last decades and contributed to Mexico's transformation from an exporter country to a corn importing country.

Juan Carlos Garavaglia, for his part, is without doubt one of the few researches who endorsed Georges Bertrand's proposal and integrates the study of agricultural systems in both the Rio de la Plata and the Mexican highlands in his works. In the latter case, he studies how in the valley of Atlixco, traditional Mesoamerican and Castilian cultures mixed, combined, and confronted one another in the use of water between the pre-Hispanic era and the post-conquest era. This work analyzes in detail the almost unknown aspects of the region's history: its abiotic environment, its vegetable and agricultural associations, the European occupation of the valley, the labor organization necessary to obtain wheat, and the search for water, pasture, and woods. In the selection and presentation of these problems, the author shows how this valley is transformed over the course of a century from an area that housed various ecosystems with a weakly humanized landscape to an area with a strongly humanized landscape and predominate wheat system dependent on irrigation. This agricultural system uses an enormous quantity of water and has a tendency to lead to environmental degradation (loss of forest resources and soil degradation). Compared to Indian agriculture which is characterized as mimetic, com-

59 Enrique Florescano, Precios del maíz y crisis agrícolas en México 1708-1810 (México: El Colegio de México, 1969). 
plex and integrative ${ }^{60}$, the new system creates environmental changes that the author studies with great detail.

Alain Musset, in the purest tradition of geographical history, argues that the disappearance of the lakes in the valleys of Mexico were not only the result of technical choices but also a philosophy of water inherited from Hippocrates and Galen, for which the stagnant waters were sources of infection. This decision is not without conflict: on the one side there was the conception of the waters for the indigenous who were in favor of a rational use of the hydraulic systems, on the other side, the Spaniards who rather than adapt to their ecosystem, destroyed it. His explanation is articulated around three main axes: the study of the established relationships between man and his environment, an analysis of the domination exercised by Mexico City over its countryside, and a description of the means exerted to exercise control of the water. All of this is explained over time, a period of four centuries, but emphasis is placed on the colonial era ${ }^{61}$.

I have analyzed the influence of this secular conflict between Spanish and indigenous, on the southern lakes (of the Valley of Mexico), where I have emphasized against the modernizing logic of development of the Spanish entrepreneurs in Chalco, which encompassed a marked transformation of the environment such as the desiccation of the lake, the opposition of indigenous communities (pueblos), which witnessed with due resentment the entrepreneurial monopolization of the waters for agricultural and industrial purposes, as well as to hinder the pueblos from independent farming. The desiccation of the lakes not only signified a loss of water for the pueblos, it also put an end to an ancient relationship between man and lake which was characterized by the use of a great variety of lake resources. And we know that when a community is stripped of one of its ecological floors, all of its other associated systems suffer a grave dislocation with negative consequences for its inhabitants. Compared to the classic thesis of the centrality of the earth in the pueblo's economy, in my analysis the

60 Enrique Florescano y Susan Swan. Breve historia de la sequía en México (México: Universidad Veracruzana, 1995), 17.

61 Juan Carlos Garavaglia, "Atlixco: el agua los hombres y la tierra en un valle mexicano (siglos XVIXVII)", en Tierra, agua y bosques: historia y medioambiente en el México central, coord. Alejandro Tortolero (México: CEMCA- I. Mora-U de Guadalajara, 1996), 69-125. 
study of the basin is privileged, and shows that not only the land alone was important, but also that the communities' way of life was supported by the utilization of various basin resources where water and forests were crucial, too ${ }^{62}$.

Moving into deeper waters, throughout various works, Micheline Cariño demonstrates the private companies' push, through a system of concessions commonly used during the Porfiriato (1877-1911), to overexploit the pearl banks in the Gulf of California. One book addresses the topic of fishing zones and pearl cultivation. The best climatic conditions for the growth of pearl oysters corresponds to the tropical and subtropical regions in a geographical area extending from the more humid zones to the desert areas (Persian Gulf and Gulf of Mexico). In Baja California, the beauty and quality of its pearls and their nacres quickly led this privileged region to become overexploited and depleted of its pearl banks ${ }^{63}$.

This exploitation is described by the author over the long duration, since the arrival of the Spanish in 1533 until 1940. This is divided into five periods. Between 1553 and 1696, the fishing of pearls was the principal motivation for the exploitation and demarcation of the coasts of Baja California. By the mid XVIII century, this activity financed mining operations and the settlement of the southern region of Baja California. Between 1830 and 1873, the exploitation of pearls was carried out on a medium scale, and the main consequences were the growth of La Paz's population and the intensification of local trade and the steady growth of employees. In 1874, the introduction of the diving suit intensified the

62 Alain Musset, De l'eau vive à l'eau morte: enjeux techniques et culturels dans la vallée de Mexico (Paris: ERC, 1991). Alain Musset, "De Tláloc a Hipócrates. El agua y la organización del espacio en la cuenca de México, siglos XVI al XVIII", en Tierra, agua y bosques: historia y medioambiente en el México central, coord. Alejandro Tortolero (México: CEMCA- I. Mora- U de Guadalajara, 1996), 127-177.

63 For the classic thesis see Romana Falcón, "Bajo la imperiosa necesidad de vivir", en México in transition: new perspectives in mexican agrarian history, eds. A. Escobar y M. Buttler (México: CIESAS, 2013), 111-148. For the advantages of a basin analysis see Juan Humberto Urquiza, "La conservación de las cuencas hidrológicas: una lucha por la nación”, Copia mecanoescrita, 2014. Alejandro Tortolero, Notarios y Agricultores. Crecimiento y atraso en el campo mexicano, 1780-1920 (México: Siglo XXI, 2008). Alejandro Tortolero, Water and revolution, 2013. It is worth recalling the words of Braudel: "For centuries man is prisoner of the climate, vegetation, animal populations, crops, a delicate balance one cannot part from without running the risk of disrupting everything", Fernand Braudel, La longue durée, 1958. 
fishing of oyster pearls. Thus began the large-scale fishing of pearls that impacted the economy, society, and local politics. This in turn led to an increase in the local accumulation of capital. In 1903, the massive oyster pearl culture brought about important innovations which ensured the gradual exploitation of pearl banks until 1914. The final phase from 1915 to 1940 is characterized by the open access to the pearl banks and by their exploitation. The end of pearl fishing produces a grave recession on the regional economy with grave social consequences ${ }^{64}$.

To these authors we can add the works of Niederberger $(1987)^{65}$, Soberanis $(1996)^{66}$, Cramaussel (1999) ${ }^{67}$, and Morales Moreno (1996) ${ }^{68}$, who credit the influence of French historiography ${ }^{69}$. The contributions of these authors consisted in modifying the traditional historiography that contemplated -in general terms - nature as something immovable in the midst of dynamic social processes. If history was a science centered on the study of change, nature, while passive and unchanging, did not have a place as an object of investigation. In essence the environment was treated by its "arcadienne" facet, which considered man as part of the harmony of the world, encouraging him to love and respect the environment. However, Crosby soon showed us that this harmony was only apparent, and there also exist an imperialist ecology that intends to create an instrumental world in order to exploit its resources on behalf of man. Upon showing us the environment, it became a factor that needed to be taken into ac-

64 Micheline Cariño y R Monteforte, Une histoire mondiale des perles et des nacres: pêche, culture, commerce (Paris: L'harmattan, 2005).

65 Micheline Cariño Olvera, "Les mines marines du Golfe de Californie. Histoire de la región de la Paz a la lumière des perles" (Thèse de doctorat, EHESS, 1998).

66 Christine Niederberger, Paleopaysages et archeologie pre-urbaine du bassin de Mexico (México: CEMCA, 1987).

67 Alberto Soberanis, "Geografía y botánica: el paisaje mexicano visto por los viajeros franceses de la Commission Scientifique du Mexique (1864-1867)", en Tierra, agua y bosques: historia y medioambiente en el México central, coord. Alejandro Tortolero (México: CEMCA- I. Mora- U de Guadalajara, 1996), 179-218.

68 Chantal Cramaussel, "Sociedad colonial y depredación ecológica. La provincia de Santa Bárbara", en Sociedad y medioambiente en América, comp. Bernardo García Martínez y Alba González Jácome (México: COLMEX/Sociedad Panamericana de Geografía, 1999), 93-107.

69 Humberto Morales Moreno, "Medioambiente, recursos productivos y los proyectos de industrialización en México a finales del siglo XIX: 1890-1910”, en Tierra, agua y bosques: historia y medioambiente en el México central, coord. Alejandro Tortolero (México: CEMCA-I. Mora-U de Guadalajara, 1996), 361-396. 
count. From the environmental approach, we study the bidirectional relationship that man establishes with his environment, the technologies he uses to transform it, and his modes for environmental management and its production guidelines. Environmental history therefore results from a dialogue between the humanities and natural sciences, which operates through three essential axes. The first is to consider the consequences of human intervention in nature as a central key. The second is founded on our ideas of nature having a necessary historical character that are bound in multiple ways with interests, values, and behaviors related to other planes of our existence, and which play an important role in our relationship with the natural world. The third is the obvious fact that our environmental problems of today have their origins in our interventions in the ecosystems of yesterday ${ }^{70}$.

Thus, the importance of French historiography in the birth of environmental history is recognized worldwide ${ }^{71}$, and in Latin America where the influence of the Annales in the emergence of Latin American environmental history has never been doubted ${ }^{72}$. Although it is also true that French historiography conquered the entire world during the past century, including Latin America, it did not do so through its contributions to environmental history but rather through its contributions to the quantification and study of structures ${ }^{73}$. In this context it is clear that the contributions in environmental matters are rather modest in comparison to what occurred in other areas of study, as we shall see next.

70 See Alejandro Tortolero, Tierra, agua y bosques..., 9-48.

71 The French historiography is not the only contributor to this change. Other traditions that integrate the bidirectional relationship between man and nature can be seen in Alejandro Tortolero, Tierra, agua y bosques..., 11-48. See also Donald Worster, The ends of, 293.

72 See Donald Worster, The ends of, 291, 292. Alfred Crosby, The past and..., 1177-1189. Richard Grover, "Editorial", Environnement and History Vol. 1 No. 1 (1995): 1. Ramachandra Guha, The fissured land..., 7. Ramachandra Guha, How much should..., 21. Juan Martínez Alier, "Temas de historia económica-ecológica”, en Historia y ecología, eds. Manuel González de Molina y Juan Martínez Alier (Madrid: Revista Ayer-Marcial Pons- Librero, 1993), 19. J. R. McNeil, "Observations on the nature and culture of environmental history”, History and Theory Vol. 42 No. 4 (2003): 14. J.R. McNeil, J. A. Padua M. Rangarajan, Environmental..., 4.

73 Alejandro Tortolero, Tierra, agua y bosques..., 11. Gustavo Zarrilli, “Argentina, tierra de promisión. Una interpretación historiográfica de las relaciones entre la historia rural y la historia ambiental en la Argentina", Revista de Historia Iberoamericana Vol. 7 No. 1 (2014): 112, 113; Reinaldo Funes, "Presentación”, en Naturaleza en declive (España: Centro Francisco Tomás y Valiente, UNED-Valencia, 2008), 13. Stefania Gallini, "Invitación a la historia ambiental", Cuadernos Digitales Vol. 6 No. 18 (2002). 


\section{French Exception or Also Latin American?}

The answer to this question or situation appears to me to have various causes, the first of which references historiographical currents. In Latin America and particularly in Mexico, the historiographical renewal was realized at the hand of studies inspired by historical materialism ${ }^{74}$. Even when the Annales School contributes to this renovation, it does so at the hand of the history of economic structures and of the Pierre Vilar's readings of the past ${ }^{75}$. Indeed, the latinamericanist historiography imported Vilar's marxism and forgot about the excellent geographer that meticulously observed the geographic environment ${ }^{76}$.

Neither geographic history, nor the physical environment, nor agricultural systems, are the preferred objects of study in this renewal. On the contrary, prices, commerce, labor, social revolutions, class struggles, and the modes of production attract historians.

The other element that must be noted refers to the same force that environmental studies have had in the Annales School. While we have already noted an extensive tradition of studies in the pages of the Annales, it is also true that many of these works were centered on economic, social, or legal history and not on nature or ecology. Because of this, Bertrand's 1975 criticism and his invitation for historians to study the dialectical relationships between rural societies and the evoution of the environment was poorly received by French historians, as demonstrated by Geneviève Massard-Guilbaud thirty years later ${ }^{77}$. For her, a sign of this is the syn-

74 Roger Chartier, "L'histoire aujourd'hui: doutes, défis, propositions", en Historia a debate, ed. Carlos Barros (España: Santiago de Compostela, 1995), 120.

75 See Carlos Sempat, Ciro Cardoso, Horacio Ciafardini, Juan Carlos Garavaglia y Ernesto Laclau, Modos de producción en América Latina (México: Siglo XXI, 1989).

76 See Rosa Congost y Pablo Luna, Pierre Vilar: une histoire totale, une histoire en construction (España: Editorial Universidad de Granada-Publicacions Universitat de València, 2004).

77 This lamentable oversight was part of the Spanish language edition of his work published by Critica, where the editors signaled out that the natural environment was abbreviated in the translation and referred to the expanded version in French and Catalan. This is despite that Vilar sets up that in its origins his thesis was a geographic investigation and it is widely claimed as part of that generation of brilliant French geographers and historians like Febvre, Bloch, and Lefebvre. He signals out his debt with Vidal when he affirms that Vidal taught him how see the landscapes and objects of study: "If I would not have contemplated the cellars of the old Barcelonan houses, measured the "barques de mitajana" over the beaches of the Marina, followed the itinerary of the charioteers that transported 
thesis of the New History, which in 1978 did not have a provision for the environment but only for geographical history, while Le Goff and Nora included climate, but not the environment. Even when it comes to economic history, themes such as growth and crises that focus on the Industrial Revolution - this transformation is not studied in relation to its consequences for ecosystems; nor is historical demography interested with bacterial pollution or that of the air; even less so the labor movement, which studies salaries and working conditions, but not environmental injustices. In sum, if French historiography has occupied itself with the geographical environment since Febvre, Bloch, and Braudel, man has not been included in this history, and thus this program for an environmental history launched in 1974 has not been realized ${ }^{78}$.

The third element refers us to the scope of the organizations. The organizational mechanisms that were implemented in order to create an environmental history of Latin America only appear in the last decade of the past century. The first congresses date back to 1994, and the formation of a society of Latin American environmental history dates to $2006^{79}$. During this period, the linguistic turn and cultural history gained ground, and while subaltern studies, gender studies, and microhistory were spreading with great force, environmental history did not share the vigor of these disciplines. To put the situation into perspective, while these organization mechanisms played a role in stimulating the emergence of Latin American

bales of printed calico, barrels of pellets, and gold coins, photographed by the Masaías del Vallès and of the paper mills of Carme and of Capellades, compared irrigated Urgell with arid Urgell and with the Monegros desert, passing ten times through the port of Bonaigua and discovering in the depths of the Pyrenean, the high bell towers of Bof, would I have understood something from the report of doctor Santpons about the human overcrowding of Barcelona in 1780, of the accounts of the boat bosses from Canet and Calella, of the invoices of the merchant-manufacturer Alegre to his carriers, of the trip of Young...”. Pierre Vilar, Cataluña en la España Moderna, (España: Ed. Grijalbo, 1978), 17. Geography, then, places us in the concrete, in the limits of the field of observation.

78 Geneviève Massard-Guilbaud, "De la "part du milieu" à l'histoire de l'environnement", Le Mouvement Vol. 3 No. 200 (2002): 64-72. Geneviève Massard-Guilbaud, "Ville et environnement", Histoire Urbaine Vol. 1 No. 18 (2007): 5-21.

79 Geneviève Massard-Guilbaud, Ville et environnement (2007), 6-7. F. Locher y G. Quenet "L'histoire environnementale: origines, enjeux et perspectives d'un noveau chantier", Revue d'histoire moderne et contemporaine Vol. 4 No. 56 (2009): 7-38. Develop one position that invites a debate; indisputably, the founders had an influence on environmental history; there are also several critiques by Massard worth noting. 
environmental history, it is also true that with these, the French influence diminished ${ }^{80}$.

\section{ConcLusion}

Throughout this work we have demonstrated that the influence of the French historiography of the Annales School contributed to the birth and diffusion of environmental history in Latin America. Nevertheless, the little attention that French historians gave to the environment generated a vacuum during the last third of the twentieth century and has only recently begun to be filled through new works ${ }^{81}$. We have seen that the Annales School -since the 1930s (Febvre and Bloch)- has promoted an environmental history intimately linked with history and geography. This can be observed in La Mediterranée: the environment is at the same time present as a restriction that as a slow construct, under the mark of adaptation and control -and to a certain extent- of the nature of human societies, and with Braduel under the mark of the long-term. From the 1970s the $A n$ nales went the direction of microhistory to the detriment of environmental history except in some aspects, like those of the history of mountains or the history of water ${ }^{82}$.

80 The first symposium of environmental history was heled in Stockholm in 1994 where the fundamental theme was the environment (Threatened peoples and environments in the Americas). There Alain Musset and A. Tortolero coordinated a symposium over "The Environment, Agriculture, and Industry in the Basin of Mexico: Various Centuries of Transformation" which led to the first book of environmental history in Mexico, Alejandro Tortolero, Tierra, agua y bosques: historia y medio ambiente en el México central (México: CEMCA-I. Mora- U de Guadalajara, 1996). This was followed by various reunions in the Congresses of Americanists and of Environmental History (Chile, 2003, Cuba, 2004, Carmona, 2006, Belo Horizonte, 2008, La Paz, 2010, Leyva, 2012).

81 For a glimpse of the Symposium of American Environmental History of Havana in 2004, the second most important delegation of the congress after Mexico (45) was the North American one with 15. From Europe, there were only 4 Spaniards and 3 Englishmen: see Omayra Perales Martínez, "El II Simposio Internacional de Historia Ambiental Americana La Habana, 25 y 27 de octubre, 2004", Investigaciones Geográficas (Mx) No. 56 (2005): 179-181.

82 The chair of Environmental History commences in EHESS with Genevieve Massard in 2006, and although there are no journals such as the North American review Environmental History (1976) or the British review Environment and History (1995), a recent issue of Annales is dedicated to the environmental issues (2011) as is one of the issues Revue d'Histoire Moderne et Contemporaine in 2009. In the United States the American Society for Environmental History was created in 1976, and one was also created in Europe in 1999. McNeil, Observations on the..., 11. 
While this was occurring, the advance in North American Environmental History was decisive and its contributions have served to fill the gap that for decades French historiography left open.

While the first push contributed to the birth of a Latin American environmental history, we are now in another stage where we expect to count on works that go beyond the distributive aspect of natural resources, where we should observe their forms of management, their integration in a way of life, in a worldview. Here environmental history will be decisive for the study of communities whose evolution or historical development is linked to the appropriation or exploitation of a natural resource; for the theoretical reflection of the environmental problem in historical perspective; for the analysis of the relationships that humans establish with their natural surroundings; for the description and analysis of changes in the landscape; for the historical revision of social and environmental conflicts; and for the study of political and institutional frameworks that have permitted the processes that degrade the environment. In sum, the tasks are many but the advances and contributions during these last decades permit us to be optimistic about the future of Latin American environmental history.

\section{BiBLIOGRAPHY}

Aguirre Rojas, Carlos. "Braudel en las Américas. Ensayo de comparación de dos intercambios transculturales". Signos Históricos Vol. 3 No. 2 (2000): 49-80.

Aymard, Maurice. "Ruggiero Romano y la historia europea". En Construir la historia. Homenaje a Ruggiero Romano, coordinado por Alejandro Tortolero. México: UAMI-COLMEX-ColMich- I.Mora -UAEM, 2002, 39-48.

Bakewell, Peter. "An interview with François Chevalier". Hispanic American Historical Review Vol. 64 No. 3 (1984): 421-442.

Berthet, Bernard. "De la forêt inutile à la forêt précieuse dans le Haut-Jura, au XVe et au XVIe siècle". Annales ESC Vol. 6 No. 2 (1951): 145-153.

334 Bertrand, Georges. "Pour une histoire écologique de la France rurale". Dans Histoire de la France Rurale, Tomo 1, sous la direction de Georges Duby et Armand Wallon. Paris: Seuil, 1975, 34-113. 
Bloch, Marc. La société féodale. Paris: Albin Michel, 1949.

Bloch, Marc. Les caractères originaux de l'histoire rurale française. Paris: Armand Colin, Les belles lettres, 1931.

Bloch, Marc. Apologie pour l'histoire. Paris: A. Colin, 1949.

Bloch, Marc. Apología para la historia o el oficio de historiador. México: FCE, 2003.

Braudel, Fernand. La Méditerranée et le Monde Méditerranéen à l'époque de Philippe II. France: Armand Colin, 1949.

Braudel, Fernand. El mediterráneo y el mundo mediterráneo en la época de Felipe II. México: FCE, 1992.

Braudel, Fernand. "La longue durée". Annales ESC Vol. 13 No. 4 (1958): 725-753.

Burke, Peter ed. Economy and society in early modern Europe: essays from Annales. New York: Harper and Row, 1972.

Cariño Olvera, Micheline. "Les mines marines du Golfe de Californie. Histoire de la región de la Paz a la lumière des perles". Thèse de doctorat, EHESS, 1998.

Cariño, Micheline y Monteforte, R. Une histoire mondiale des perles et des nacres: pêche, culture, commerce. Paris: L'harmattan, 2005.

Chartier, Roger. "L'histoire aujourd'hui: doutes, défis, propositions". En Historia a debate, editado por Carlos Barros. España: Santiago de Compostela, 1995, 119-130.

Chevalier, François. La formación de los latifundios en México. México: FCE, 1976.

Chevalier, François. Boletín de fuentes para la historia económica de México No. 2 (1990): 37-42.

Chevalier, François. Marc Bloch trascendencia y modernidad. Caracas: Fondo Editorial de la Universidad José María Vargas, 1990.

Chevalier, François. La formation des grandes domaines au Mexique. Terre et société, XVIe, XVIIe, XVIIIe siècles. Paris: Karthala, 2006. Chevalier, François. "Orígenes y elaboración de los grandes latifundios en México. Tierra y sociedad en los siglos XVI y XVII". Signos Históricos Vol. 17 No. 17 (2007): 33-43.

Congost, Rosa, y Pablo Luna (coord.). Pierre Vilar: une histoire totale, une histoire en construction. España: Editorial Universidad de GranadaPublicacions Universitat de València, 2004.

Cramaussel, Chantal. "Sociedad colonial y depredación ecológica. La pro- 
vincia de Santa Bárbara”. En Sociedad y medioambiente en América, compilado por Bernardo García Martínez y Alba González Jácome. México: COLMEX/Sociedad Panamericana de Geografía, 1999, 93107.

Crosby, Alfred. "The past and present of environmental history". American Historical Review Vol. 100 No. 4 (1995): 1177-1189.

Devèze, Michel. "Superficie et propriété des forêts du Nord et de l'Est de la France vers la fin du règne de François 1er (1540-1547)". Annales ESC Vol. 15 No. 3 (1960): 485-492.

Espagne, Michel y Werner, M. "La construction d'une reference culturelle allemande en France. Genèse et histoire (1750-1940)". Annales ESC Vol. 42 No. 4 (1987): 969-992.

Falcón, Romana. "Bajo la imperiosa necesidad de vivir". En México in transition: new perspectives in mexican agrarian history, editado por Escobar, A. y Buttler, M. México: CIESAS, 2013, 111-148.

Febvre, Lucien. Philippe II et la Franche-Comté, Paris: Champion, 1911.

Febvre, Lucien. La terre et l'évolution humaine. Paris: Renaissance du libre, 1927.

Florescano, Enrique. Precios del maíz y crisis agrícolas en México (17081810). México: El Colegio de México, 1969.

Florescano, Enrique, y Susan Swan. Breve historia de la sequía en México. México: Universidad Veracruzana, 1995.

Funes, Reinaldo. "Presentación". En Naturaleza en declive. España: Centro Francisco Tomás y Valiente, UNED-Valencia, 2008, 7-28.

Gallini, Stefania. "Invitación a la historia ambiental". Cuadernos digitales Vol. 6 No. 18 (2002).

Garavaglia, Juan Carlos. "Atlixco: el agua, los hombres y la tierra en un valle mexicano (siglos XVI-XVII)". En Tierra, agua y bosques: historia y medioambiente en el México central, coordinado por Alejandro Tortolero. México: CEMCA- I. Mora-U de Guadalajara, 1996, 69-125.

Goubert, Pierre. "Les villes d'europe à l'époque moderne". Revista de Historia Vol. 4 (1981): 121-132. http://ler.letras.up.pt/uploads/ ficheiros/6534.pdf

Guha, Ramachandra. How much should a person consume? Environmentalism in India and in the US. USA: University of California press, 2006.

Guha, Ramachandra. The fissured land: an ecological history of India. USA: University of California, 1993. 
Grove, Richard. "Editorial". Environnement and History Vol. 1 No. 1 (1995): 1-2.

Hawley, Amos H. "Ecological and marxian theories". American Journal of Sociology Vol. 89 No. 4 (1984): 904-917.

Hébrard, Véronique. Sur les traces d'un mexicaniste français. Constitution et analyse du fonds François Chevalier. Paris: Editions Karthala, 2005.

Hudson, James R. "Braudel's ecological perspective". Sociological Forum Vol. 2 No. 1 (1987): 146-165.

Iggers, George G. New directions in European Historiography. Middletown, CT: Wesleyan University Press, 1975.

Ingold, Alice. "Ecrire la nature. De l'histoire sociale à la question environnementale". Annales HSS No. 1 (2011): 11-29.

Lavallé, Bernard. "Introduction". En Structures et cultures des sociétés ibéro-américaines. Bordeaux: Editions du CNRS, 1990.

Le Roy Ladurie, Emmanuelle. "Histoire et environnement". Annales ESC Vol. 29 No. 3 (1974): 673- 692.

Locher, F. y Quenet G. "L'histoire environnementale: origines, enjeux et perspectives d'un noveau chantier". Revue d'histoire moderne et contemporaine Vol. 4 No. 56 (2009): 7-38.

Lombard, Maurice. "Un problème cartographie. Le bois dans la mediterranée musulmane (VIIe-XIe siècles)". Annales ESC Vol. 14 No. 2 (1959): 234-254.

Lombard, Maurice. "La chasse et les produits de la chasse dans le monde musulman (VIIIe-XIe siècle)". Annales, ESC Vol. 24 No. 3 (1969): 572-593.

Martínez Alier, Juan. "Temas de historia económica-ecológica”. En Historia y ecología, editado por Manuel González de Molina y Juan Martínez Alier. Madrid: Revista Ayer-Marcial Pons- Librero, 1993, $19-48$.

Massard-Guilbaud, Genevieve. "De la "part du milieu” à l'histoire de l'environnement". Le Mouvement Vol. 3 No. 200 (2002): 64-72.

Massard-Guilbaud, Genevieve. "Ville et environnement". Histoire Urbaine Vol. 1 No. 18 (2007): 5-21.

McNeil, J. "Observations on the nature and culture of environmental history". History and Theory Vol. 42 No. 4 (2003): 5-43.

McNeil, J., Padua, J.A. and Rangarajan, M. Environmental history, as if nature existed. Oxford: Oxford University Press, 2010. 
Molina Enríquez, Andrés. Los grandes problemas nacionales (1909). México: ERA, 1979.

Morales Moreno, Humberto. "Medioambiente, recursos productivos y los proyectos de industrialización en México a finales del siglo XIX: 1890-1910”. En Tierra, agua y bosques: historia y medioambiente en el México central, coordinado por Alejandro Tortolero. México: CEMCA-I. Mora-U de Guadalajara, 1996, 361-396.

Moriceau, Jean Marc. "Grandes haciendas y explotaciones agrarias en Francia entre el siglo XVII y el XIX. Por un intento de caracterización”. Signos Históricos Vol. 17 No. 17 (2007): 44-74.

Moutoukias, Zacarias. "Ruggiero Romano dans l'historiographie latino-américaine: idées et parcours d'un batisseur exceptionnel". En Ruggiero Romano. Incontro di studi, a cura di Paulo Betti de Lima. San Marino: giugno 2012, 2014, 59-84.

Murra, John. La organización económica del estado inca. México: Siglo XXI, 1978.

Musset, Alain. De l'eau vive à l'eau morte: enjeux techniques et culturels dans la vallée de Mexico. Paris: ERC, 1991.

Musset, Alain. "De Tláloc a Hipócrates. El agua y la organización del espacio en la cuenca de México, siglos XVI al XVIII”. En Tierra, agua y bosques: historia y medioambiente en el México central, coordinado por Alejandro Tortolero. México: CEMCA-I. Mora- U de Guadalajara, 1996, 127-177.

Niederberger, Christine. Paleopaysages et archeologie pre-urbaine du bassin de Mexico. México: CEMCA, 1987.

Perales Martínez, Omayra. "El II Simposio Internacional de Historia Ambiental Americana La Habana, 25 y 27 de octubre, 2004”. Investigaciones Geográficas (Mx) No. 56 (2005): 179-181.

Romano, Ruggiero. "Histoire des Forêts et histoire economique". In Actes $\mathrm{du}$ Colloque sur la forêt (Besançon, 21-22 octubre 1966), Cahiers d'études comtoises, Les Belles Lettres No. 12 (1967): 59-66.

Romano, Ruggiero. "Quand la montagne a aussi une histoire". Mélanges offerts à Jean-François, ed. Martin Körner y François Walter. Berne: P. Haupt, 1996, 285-288.

Sempat, Carlos, Ciro Cardoso, Horacio Ciafardini, Juan Carlos Garavaglia y Ernesto Laclau. Modos de producción en América Latina. México: 
Siglo XXI, 1989.

Soberanis, Alberto. "Geografía y botánica: el paisaje mexicano visto por los viajeros franceses de la Commission Scientifique du Mexique (1864-1867)". En Tierra, agua y bosques: historia y medioambiente en el México central, coordinado por Alejandro Tortolero. México: CEMCA- I. Mora- U. de Guadalajara, 1996: 179-218.

Tortolero, Alejandro (Coord.). Tierra, agua y bosques: historia y medioambiente en el México central. México: CEMCA-I. Mora- U. de Guadalajara, 1996.

Tortolero, Alejandro. Notarios y agricultores. Crecimiento y atraso en el campo mexicano, 1780-1920. México: Siglo XXI, 2008.

Tortolero, Alejandro “Water and revolution in Morelos: 1850-1915”. In A Land between waters. Environmental Histories of Modern Mexico, edited by Christopher R. Boyer. USA: The University of Arizona Press, 2013, 124-149.

Troll, Carl. "Die geographischen Grindlagen der Andinen Culturen und des Inkaeriches”. In Ibero Amerikanisches Arkiv No. 5 (1931).

Urquiza, Juan Humberto. "La conservación de las cuencas hidrológicas: una lucha por la nación”. Copia mecanoescrita, 2014.

Van Young, Eric. "Mexican rural history since Chevalier: the historiography of the colonial hacienda". Latin American Research Review Vol. XVIII No. 3 (1983): 5-61.

Vidal de la Blache, Paul. Principes of human geography. New York: Henry Holt and Co, 1926.

Vilar, Pierre. Cataluña en la España Moderna. España. Crítica, 1978.

Wachtel, Nathan. "Ruggiero Romano, un historiador en la Escuela de Altos Estudios en Ciencias sociales". En Construir la historia. Homenaje a Ruggiero Romano, coordinado por Alejandro Tortolero. México: UAMI- ColMex- Colmich- I.Mora- UAEM, 2002, 49-57.

Wachtel, Nathan. "Ruggiero Romano, l'Ecole des hautes études en sciences sociales et l'Amérique Latine". In Ruggiero Romano. Incontro di studi. a cura di Paulo Betti de Lima. San Marino: Giugno 2012, 2014, 43-58.

Woronoff, Denise. "Histoire des forêts françaises, XVIe-XXe siècles. Résultats de recherche et perspectives". Cahiers du CRH No. 6 (1990): 6. 
Worster, Donald (ed.). The ends of the earth. Cambridge: University Press, 1988.

Zarrilli, Gustavo. "Argentina, tierra de promisión. Una interpretación historiográfica de las relaciones entre la historia rural y la historia ambiental en la Argentina". Revista de Historia Iberoamericana Vol. 7 No. 1 (2014): 107-132.

It seems to me that by going away from economic history and making an alliance with the anthropology and microhistory applied to the Annales approach to studying society, they hinder the fulfillment of a program where environmental history would have had a more prominent place. Neither the history of food nor archaeology managed to propel this project and this is despite the efforts of François Sigaut or of the archaeologists who managed to extend the periodization of history from 5000 to more than 12 millennia, breaking the exclusive bond between history and written sources, incorporating, in turn, new analytical methods and utilizing very developed scientific techniques to analyze grains, pollen, metal objects, and bones, creating and making available, in this manner, a radically new source base for environmental history and to analyze the relationship between nature and man.

Para citar este artículo: Tortolero Villaseñor, Alejandro "The Annales 340 School and the Environmental History of Latin America", Historia Caribe Vol. XII No. 30 (Enero-Junio 2017): 301-340. DOI: http://dx.doi. org/10.15648/hc.30.2016.01 